\title{
Pengaruh Konten Radikal Terhadap Sikap Radikalisme \\ (Analisis Berdasarkan Theory Of Planned Behavior dari Ajzen Dan Fishbein)
}

\author{
Nuril Mubin ${ }^{1}$, Setyaningsih ${ }^{2}$ \\ ${ }^{1}$ Program Studi Psikologi, Fakultas Ilmu Sosial dan Ilmu Budaya \\ Universitas Trunojoyo Madura
}

\begin{abstract}
This study aims to determine the effect of radical content on the attitude of radicalism (analysis based on the theory of planned behavior of Ajzen and Fishbein). This study uses a quantitative approach. The number of samples in this study were users of active social media and following radical content with a total of 393 people. Sampling using purposive sampling technique(non-probability sampling). The instruments in this study are the scale of radical content and the scale of radicalism. The analysis of the data used is simple linear regression using the 23.0 for windows SPSS (statistical product and service solution) program. The results of this study indicate that the influence of radical content on radicalism is determined. Based on $F$ count of 806.47 and probability of probability 0,000 $(0,000<0.05)$ which means that the hypothesis is accepted, therefore there is a positive influence of radical content on the attitude of radicalism. The amount of the contribution or effective contribution of the influence of radical content on radicalism attitudes is $67,3 \%$ while the remaining $32,7 \%$ is influenced by other factors not measured in this study.
\end{abstract}

Keywords: radical content, radicalism

\begin{abstract}
Abstrak
Penelitian ini bertujuan untuk melihat pengaruh konten radikal terhadap sikap radikalisme (analisis berdasarkan Teori Planned Behavior dari Ajzen \& Fishbein). Penelitian ini menggunakan pendekatan kuantitatif. Sample dalam penelitian ini berjumlah 393 orang yang aktif mengikuti konten radikal di media sosial. Teknik sampling yaitu Purpusive sampling (non-probability sampling). Alat ukur dalam penelitian ini menggunakan skala konten radikal dan skala sikap radikalisme. Analisis data yang digunakan regresi linier, SPSS seri 23. Hasil dari penelitian ini adalah ada pengaruh positif konten radikal terhadap sikap radikalisme. Didasarkan pada hasil hitung $\mathrm{F}=806,47$ dan probabilitas $0.000(0.000<0.05)$. Sumbangan efektif konten radikal terhadap sikap radikalisme sebesar $67,3 \%$ sementara sisanya $32,7 \%$ dipengaruhi faktor lain.
\end{abstract}

Kata kunci: radikalisme, kontan radikal

\section{Pendahuluan}

Radikalisme bukanlah hal baru bagi masyarakat Indonesia banyak kejadian 
maupun kelompok radikal yang ada di Indonesia. kasus kejadian teror di Surabaya yang dilakukan oleh satu keluarga dalam aksi pengeboman contohnya, (kompas 19 mei 2018) kejadian dimulai dari sang ayah Dita Soepriarto yang melepas istrinya Puji Kuswati bersama kedua putrinya Fadhila dan Pamela di depan GKI (Gereja Kristen Indonesia) jalan Diponegoro, lalu Dita melaju dan menabrakan mobilnya yang berisi bom ke GPPS (Gereja Pantekosota Pusat Surabaya) sementara istri dan kedua putrinya meledakan diri mereka dikompleks GKI.

Banyaknya kejadian teror tidak terlepas dari paham yang dianut para pelaku, paham radikalisme dianggap sebagai salah satu penyebab munculnya kejadian seperti itu. Sejak seseorang mulai menutup dirinya untuk menerima perbedaan cara berpikir dan budaya, merasa keyakinannya superior, lebih murni dan mengajak orang lain untuk memiliki cara berpikir yang sama dengan dirinya dengan berbagai macam cara, dari yang persuasif hingga paksaan, intimidasi, group atau social bullying dan bentuk lainnya. Tidak hanya kasus yang berkaitan dengan agama radikalisme juga bisa berlandaskan pemikiran yang menganggap bahwa suku atau kelompoknya yang paling sempurna dibanding kelompok atau suku lain, hal itu seperti kasus konflik antar suku di Sampit Kalimantan atau kasus kelompok OPM ( Organisasi Papua Merdeka) dimana kelompok ini beranggapan bahwa ideologinya adalah yang paling benar dan tidak mengakui adanya pancasila sebagai dasar negara. Tidak hanya OPM kejadian dimasa lalu juga pernah terjadi misalnya kelompok PKI (Partai Komunis Indonesia) dimana mereka memiliki landasan tersendiri mengenai ideologi negara dan berusaha mengganti ideologi negara Indonesia yang berlaku yaitu Pancasila dengan ideologi Komunisme.

Istilah radikalisme berasal dari bahasa Latin radix yang berarti akar, pengkal, bagian bawah, atau bisa juga berarti menyeluruh, habis-habisan dan amat keras untuk menuntut perubahan. (Muslih, 2015) Dalam bahasa Inggris, kata radikal memiliki makna ekstrem, menyeluruh fanatik, revolusioner, fundamental. Sedangkan radikalisme adalah doktrin atau praktek yang mengenut paham radikal.

Menurut KBBI (Kamus Besar Bahasa Indonesia) radikalisme adalah paham atau aliran yang radikal dalam politik, paham atau aliran yang menginginkan perubahan sosial dan politik dengan cara kekerasan atau drastis atau bisa diartikan sikap ekstrem dalam aliran politik. Dalam Kamus Politik, yang dimaksud radikal adalah orang yang ingin membawa ide-ide politiknya ke akar-akarnya, dan mempertegas dengan cara yang sempurna doktrin-doktrin yang dihasilkan oleh usaha tersebut. (Roger, 2013) 

Sedangkan menurut Khamid (2016) radikalisme adalah "paham atau gerakan yang berpandangan kolot dan sering menggunakan kekerasan dalam mengajarkan keyakinan mereka, suka melakukan tindakan-tindakan teror, yang berarti menakut-nakuti atau menyebabkan ketakutan". Tujuan dari paham radikalisme ini adalah mengadakan perubahan sampai keakarnya dan untuk mewujudkan tujuan ini mereka selalu menggunakan cara kekerasan serta menentang struktur masyarakat yang ada, mereka menawarkan program yang cermat dan memiliki landasan filsafat yang kuat untuk membenarkan adanya rasa ketidakpuasan terhadap kekuasaan yang berlaku saat ini. Radikalisme memiliki dampak yang membahayakan. Biasanya radikalisasi ini tumbuh berkaitan erat dengan ketidakadilan ekonomi, politik, dan lainnya. (Rokhmad, 2012)

Abdullah Sumrahadi (Wibowo,2012) mengemukakan bahaya radikalisme yang tersebar dimasyarakat, antara lain: Kehidupan sosial dan masyarakat diliputi oleh rasa kekhawatiran, perasaan menjadi tidak aman, dan tertekan saat melakukan aktivitas. Merusak sendi-sendi politik, karena politik dijadikan sebagai alat atau sarana melakukan kejahatan oleh pihak tertentu serta kesewenag-wenangan oleh penguasa. Kehidupan ekonomi menjadi tidak stabil karena sentimen pasar cenderung mengikuti kejadian politik nasional maupun internasional disuatu tempat. Paham radikal mengakibatkan pengembangan atau penanaman nilai-nilai budaya menjadi menipis karena seolah budaya masyarakat larut dalam suasana anarkis. Kehidupan beragama dan berkelompok menjadi tidak bebas dikarenakan adanya bayang-bayang kekuasaan dan ketertindasan oleh kelompok dominan. Dengan demikian sangat berbahaya bila paham radikal ini berkembang di masyarakat karena tidak menutup kemungkinan munculnya konflik-konflik antara kelompok maupun golongan karena berselisih paham, selain menyebabkan konflik antar kelompok hal ini juga akan merusak tatanan sosial dan budaya yang sudah berkembang di masyarakat.

Badan Nasional Penangulangan Terorisme (BNPT) merilis data penyebaran pelaku radikalisme berdasarkan usia pelaku radikalisme. 
Tabel 1.1

Data Perilaku Radikalisme

\begin{tabular}{|l|l|l|}
\hline $\begin{array}{l}\mathrm{N} \\
\mathrm{o}\end{array}$ & $\begin{array}{l}\text { Berdasarkan } \\
\text { usia }\end{array}$ & Persentase \\
\hline 1 & $<20$ & $11,8 \%$ \\
\hline 2 & $21-30$ & $47,3 \%$ \\
\hline 3 & $31-40$ & $29,1 \%$ \\
\hline 4 & $>40$ & $11,3 \%$ \\
\hline \multicolumn{3}{|c|}{ (sumber: www.bnpt.go.id) }
\end{tabular}

Kelompok radikal menyadari betul strategi untuk merekrut mereka yang tergolong generasi milenial, mereka menggunakan pendekatan dua arah yaitu memengaruhi melalui dialog-dialog yang aktif dan berdebat seputar paham yang mereka yakini, selain itu juga melalui tulisan yang berkembang di media massa. Tujuan dari hal ini yaitu kelompok radikal ingin memengaruhi sikap kaum milenial agar memiliki paham dan sikap yang sama seperti kelompoknya. Menurut Baron dan Byrne (2012) sikap adalah evaluasi terhadap aspek-aspek dunia sosial, sering kali sikap seseorang ambivalen yaitu mengevaluasi objek sikap baik secara positif maupun negatif. Sikap individu tidak terbentuk begitu saja, menurut Rahman (Baron \& Byrne, 2012) secara umum bahwa sikap merupakan hasil dari proses belajar, seorang anak yang dilahirkan tidak membawa kecenderungan sikap tertentu terhadap objek sikap yang ada diluar dirinya. Sikap baru terbentuk setelah melakukan kontak dengan lingkungan sekitarnya. Sedangkan sikap radikalisme sendiri adalah evaluasi atau respon individu mengenai paham yang bertujuan untuk melakukan perubahan secara mengakar dengan cara kekerasan atau tindakan teror yang kemudian hal itu diolah kedalam komponen kognitif berupa benar atau salah, komponen afektif berupa suka tidak suka, dan komponen konatif yang berupa tindakan melakukan atau tidak melakukan hal tersebut didalam kehidupannya. Tentu akan sangat berbahaya jika seseorang yang memiliki sikap radikal dan dibiarkan berkembang serta mempengaruhi orang lain agar ikut bergabung dengannya, hal itu akan menyebabkan kekacauan terjadi ditengah-tengah masyarakat indonesia yang terkenal akan toleransi, keberagaman serta gotong royong antar kelompok.

Sikap yang ada pada diri seseorang tidak terbentuk begitu saja melainkan dipengaruhi oleh banyak hal, menurut Azwar (2013) faktor pembentuk sikap yaitu 
pengalaman peribadi, pengaruh kebudayaan, media massa, lembaga pendidikan, pengaruh orang yang dianggap penting, agama yang dianut, serta faktor emosional. Ajzen dan Fishbein (Baron, 2012) menyatakan bahwa "keputusan untuk menampilkan tingkah laku tertentu adalah hasil dari proses rasional yang diarahkan pada suatu tujuan tertentu dan mengikuti unsur-unsur berpikir". Ada beberapa faktor yang mepengaruhi terbentuknya perilaku menurut Ajzen dan Fishbein antara lain sikap terhadap tingkah laku tertentu, norma-norma subjektif dan kontroltingkah laku yang dipersepsikan. Berikut ini adalah gambar terbentuknya tingkah laku melalui bagan di bawah ini menurut Ajzen dan Fishbein.

Gambar 1.1

Terbentuknya Tingkah laku menurut Ajzen dan Fishbein

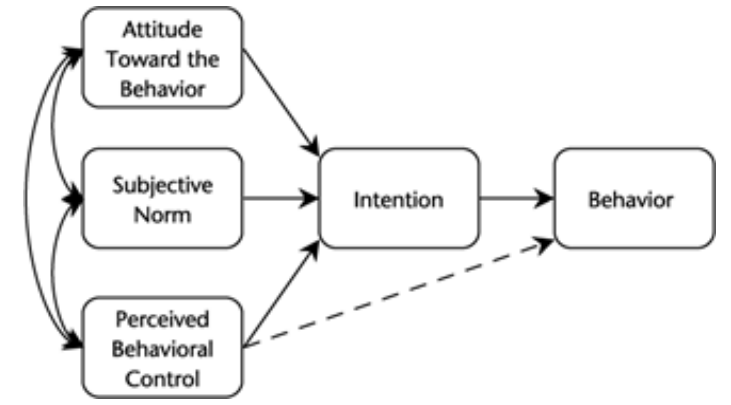

(sumber: Ajzen, 2005)

Teori ini dianggap sebagai teori yang paling tepat untuk memahami topik yang dibahas dalam penelitian ini karena dianggap mampu memprediksi dengan akurat perilaku seseorang yang akan muncul selain itu teori ini juga dianggap mampu mengetahui faktor apa saja yang memengaruhi terbentuknya sikap dan perilaku seseorang.

Teori ini menyatakan bahwa keputusan untuk menampilkan tingkah laku tertentu adalah hasil dari proses rasional yang diarahkan pada suatu tujuan tertentu dan mengikuti urut-urutan berpikir. Pilihan tingkah laku dipertimbangkan terlebih dahulu serta konsekuensi dan hasil dari setiap tingkah laku dievaluasi, dan dibuat sebuah keputusan apakah akan bertindak atau tidak, kemudian keputusan itu direfleksikan dalam tujuan tingkah laku.

Diatas disebutkan ada tiga faktor yang memengaruhi intensi yaitu sikap terhadap perilaku, norma-norma subjektif, dan kontrol perilaku yang dipersepsikan. Berikut penjelasan singkat dari masing-masing komponen diatas. 
Pertama yaitu Attitude Toward the Behavior atau sikap terhadap perilaku ini ditentukan oleh anggapan kepercayaan atau keyakinan tentang konsekuensi dari perilaku yang akan dilakukan, hal ini mengenai konsekuensi dari suatu perilaku dengan berbagai manfaat atau kerugian yang mungkin diperoleh apabila individu melakukan atau tidak melakukannya, Secara umum semakin individu memiliki evaluasi bahwa suatu perilaku akan menghasilkan konsekuensi positif maka individu akan cenderung bersikap favorable terhadap perilaku tersebut. Sebaliknya semakin individu memiliki evaluasi negatif maka individu akan cenderung bersikap unfavorable terhadap perilaku tersebut (Baron, 2012). Misalnya keyakinan mengenai paham radikalisme yang dia anggap benar, keyakinan ini akan muncul seiring pengalaman yang dialami ataupun cerita dari orang lain, kemudian individu tersebut akan mempersepsikan apakah hal itu berdampak positif atau negatif bagi dirinya dan lingkungannya, jika ia mengangap bahwa prilaku radikalisme membawa dampak positif baginya maka ia akan memiliki sikap favorable terhadap perilaku tersebut, begitu juga sebaliknya. Seseorang yang sebelumnya memiliki sikap yang positif terhadap paham radikal hal itu akan membuatnya semakin terbuka dan memiliki kecenderungan untuk tergabung kedalam kelompok radikal dan melakukan hal-hal yang bersifat radikal.

Kedua adalah Subjective Norm atau norma-norma subjektif disini norma subjektif juga dipengaruhi oleh dua hal yaitu pendapat tokoh atau orang lain yang dianggap penting atau tokoh panutan tentang apakah ia perlu untuk melakukan perilaku yang ingin dia lakukan dan seberapa jauh ia akan mengikuti pendapat orang tersebut. Artinya norma subjektif ini berkaitan dengan persepsi individu terhadap harapan orang yang dianggapnya penting dalam kehidupannya mengenai perilaku yang akan ditampilkan. Semisal pada kasus radikalisme individu yang menganggap bahwa pimpinan kelompok atau tokoh panutan yang juga memiliki aliran radikalisme menyuruh ia untuk melakukan perilaku radikal sesuai perintah atau ajaran kelompok akan memiliki kecenderugan individu untuk melakukan perilaku tersebut akan semakin besar apalagi motivasi ia untuk mengikuti perintah orang yang dianggapnya penting itu tinggi maka norma subjektif disini akan semakin mendukung munculnya perilaku tersebut. Selain itu lingkungan sosial juga turut membentuk norma-norma subjektif dalam hal ini adalah informasi-informasi 
yang didapat individu selama proses belajarnya baik secara langsung maupun tidak, termasuk juga dari internet maupun media massa yang telah dibaca oleh individu tersebut akan memengaruhi sikapnya. Media internet maupun media sosial pada saat ini mengambil peranan yang sangat penting dalam memberikan informasi dan membentuk norma subjektif kepada publik terutama kaum muda akan ideologi radikal seperti berkembangnya konten-konten radikal di Instagram maupun Facebook.

Ketiga adalah Percived Behavioral Control atau kontrol tingkah laku yang dipersepsikan hal ini berkaitan dengan persepsi individu mengenai kendala yang dihadapi terkait mudah atau tidaknya mewujudkan suatu tingkah laku tertentu, persepsi kontrol tingkah laku ditentukan oleh keyakinan individu mengenai ketersediaan sumber daya berupa peralatan, kompatibelitas, kompetensi, dan kesempatan yang mendukung atau menghambat prilaku yang diprediksi dan besarnya peran sumber daya tersebut. Semakin banyak faktor pendukung dan sedikit faktor penghambat yang individu rasakan untuk dapat melakukan suatu perilaku, maka lebih besar kontrol yang mereka rasakan atas perilaku tersebut dan begitu juga sebaliknya kemudian hal itu akan cenderung memengaruhi terwujudnya tingkah laku yang nampak pada individu. Misalnya dalam perilaku radikal individu menganggap bahwa ketersediaan dalam mendukung aksinya itu sangat melimpah yang berupa alat-alat dan bahan maka disini perilaku yang akan dituju semakin diperkuat karena ketersediaan sumber daya.

Selanjutnya yaitu intensi hal ini dipengaruhi oleh ketiga faktor diatas yaitu sikap terhadap perilaku, norma subjektif, dan kontrol terhadap perilaku dimana ketiga faktor tersebut akan berdampak langsung terhadap intensitas berperilaku individu, intensi sendiri menurut Ajzen \& Fishbein adalah penyebab dari sebuah perilaku yang nampak, intensi ini dapat meramalkan secara akurat dari berbagai kecenderungan berperilaku individu, misalnya dalam perilaku radikal intensi seseorang dalam menunjukan perilaku radikalnya bisa dilihat di pengaruhi oleh faktor apa saja dari ketiga faktor yang disebutkan diatas, selain itu juga bisa diketahui faktor mana yang memiliki pengaruh terbesar terhadap pembentukan perilaku radikal dalam diri seseorang. Oleh karena itu teori ini dianggap teori yang 
paling akurat dalam meramalkan perilaku yang akan nampak pada diri individu dan faktor apa saja yang memengaruhi munculnya perilaku tersebut.

Penelitian serupa yang membahas antara konten dan sikap pernah diteliti oleh Erbika Ruthellia David (2017) dengan judul pengaruh konten vlog dalam youtube terhadap pembentukan sikap mahasiswa ilmu sosial dan politik Universitas Sam Ratulangi, diperoleh hasil bahwa keduanya memiliki korelasi yang positif artinya terjadi hubungan searah antara konten vlog dan sikap mahasiswa, bila konten $v \log$ sering ditonton maka akan terjadi pembentukan sikap pada mahasiswa ilmu komunikasi dan politik dalam hal ini adalah sikap positif dengan maksud para mahasiswa senang dan gemar menonton $v \log$, ingin mencoba hal baru yang ada dalam vlog bahkan memiliki keinginan menjadi seorang vlogger.

\section{Sikap Radikalisme}

Menurut Baron \& Byrne (2012) sikap adalah evaluasi terhadap aspek-aspek dunia sosial sering kali sikap seseorang ambivalen yaitu mengevaluasi objek sikap baik secara positif maupun negatif dan suka atau tidak suka. Menurut Khamid (2016) radikalisme adalah paham atau gerakan yang berpandangan kolot dan sering menggunakan kekerasan dalam mengajarkan keyakinan mereka kepada kelompok lain, dan suka melakukan tindakan-tindakan teror, yang berarti menakut-nakuti atau menyebabkan ketakutan disuatu masyarakat. Berdasarkan penjelasan diatas dapat disimpulkan bahwa sikap radikalisme adalah evaluasi atau respon individu mengenai paham yang bertujuan untuk melakukan perubahan secara mengakar dengan cara kekerasan atau tindakan teror yang kemudian hal itu diolah kedalam komponen kognitif berupa benar atau salah, komponen afektif berupa suka tidak suka, dan komponen konatif yang berupa melakukan atau tidak melakukan kegiatan tersebut didalam kehidupannya.

Menurut Baron dan Byrne (2012) sikap mengandung tiga komponen yaitu;

1. Aspek kognitif, Aspek ini berkaitan dengan gejala mengenai pikiran, aspek ini berwujud pengalaman, pengolahan, dan keyakinan serta harapan individu tentang objek atau kelompok objek tertentu. Aspek ini berupa, 
kepercayaan, pengetahuan atau pikiran yang didasarkan pada informasi yang berkaitan dengan objek sikap.

2. Aspek afektif, Aspek ini berwujud proses yang berkaitan dengan perasaan tertentu seperti simpati, antipati, ketakutan, kedengkian, dan sebagainya yang ditujukan pada objek tertentu.

3. Aspek konatif, Aspek ini berwujud proses tendensi atau kecenderungan untuk berbuat sesuatu terhadap objek sikap, misalnya kecenderungan menjauhkan diri dari objek sikap, memberi pertolongan, dan sebagainya.

Menurut Azwar (2013) faktor pembentuk sikap antara lain: (1) Pengaruh Orang Lain yang Dianggap Penting yaitu seseorang yang kita harapkan persetujuannya tentang sikap yang akan kita ambil, seseorang yang tidak ingin kita kecewakan, atau seseorang yang berarti khusus bagi kehidupan kita akan banyak memengaruhi pembentukan sikap. Individu cenderung untuk memiliki sikap yang konformitas atau searah dengan sikap orang yang dianggapnya penting atau orang yang dikaguminya. (2) Pengalaman Pribadi yaitu Apa yang sudah kita alami atau sedang kita alami saat ini akan ikut membentuk dan memengaruhi terbentuknya sikap, pengalaman pribadi haruslah meninggalkan kesan yang kuat, karena itu sikap akan lebih mudah terbentuk apabila pengalaman pribadi tersebut terjadi dalam situasi yang melibatkan faktor emosi atau sangat berkesan. (3) Pengaruh Kebudayaan yaitu dimana kita hidup bersosial dan dibesarkan, akan mempunyai pengaruh besar terhadap pembentukan sikap dan kepribadian kita. Hal ini tidak lain terjadi pada pola prilaku yang konsisten yang menggambarkan sejarah perlakuan yang kita alami. (4) Media Massa yaitu Sebagai sarana komunikasi berbagai bentuk media massa baik cetak maupun online sama besarnya dalam peranan penting guna pembentukan opini dan kepercayaan orang, media massa membawa pesan dan sugesti yang dapat mengarahkan opini seseorang kemudian hal itu akan memberi landasan kognitif yang baru mengenai suatu kejadian atau pola pikir. (5) Lembaga Pendidikan dan Lembaga Agama yaitu keduanya meletakan dasar pengertian dan konsep moral kedalam diri individu. Konsep tersebut juga menekankan sistem kepercayaan maka tidak heran jika konsep tersebut ikut berperan dalam pembentukan sikap seseorang. (6) Pengaruh Faktor Emosional yaitu Suatu bentuk sikap merupakan pernyataan yang didasari oleh emosi yang berfungsi sebagai 
pengalihan bentuk pertahanan ego, Sikap yang demikian bisa bersifat sementara atau bertahan lama dan menetap.

Mubarok (Jainuri, 2016) mengatakan ada beberapa faktor yang menyebabkan munculnya paham radikalisme dimasyarakat, antara lain:

1. Muncul akibat pemahaman terhadap teks-teks agama yang dimaknai secara dangkal tanpa melihat secara keseluruhan dan mendalam tanpa memperhatikan norma masyarakat yang ada.

2. Muncul akibat persoalan ketidakadilan sosial, ekonomi, dan politik dalam tatanan dunia yang dianggap hanya dikuasai oleh kaum atau kelompok tertentu.

3. Muncul akibat keinginan yang kuat untuk mendirikan negara atau wilayah sesuai dengan norma keyakinan atau agama yang dianut dan ditetapkan secara utuh.

4. Muncul akibat pembelaan atas nama kehormatan kelompok atau aliran yang mereka anut yang mereka dianggap telah dilecehkan oleh pihak lain atau penistaan agama dan pemberantasan kemaksiyatan yang beredar dimasyarakat.

\section{Konten Radikal}

Konten radikal adalah informasi atau gagasan yang ada didalam media baik online maupun cetak yang didalamnya mengandung unsur radikal seperti mengajak dan memperbolehkan menggunakan kekerasan untuk orang yang berbeda faham dengan kelompoknya, bersikap intoleran serta melakukan propaganda untuk melakukan perlawanan guna membuat perubahan sistem yang dianggap sesuai oleh kelompoknya. Ciri-ciri konten radikal dikemukakan oleh Jainuri (2016) dan Badan Nasional Penangulangan Teroris (BNPT) karena pendapat keduanya hampir memiliki kesamaan pada garis besarnya yaitu: (1) Mempunyai prinsip penafsiran ajaran kelompok yang berbeda atau berlawanan dengan tradisi yang sedang berlaku atau gerakan kelompok yang sudah muncul. (2) Menggunakan kekerasan yang dianggap benar dalam ajaran kelompoknya, kekerasan ini termasuk tindakan melawan pemerintah atau aparatur dan memperbolehkan membunuh seseorang yang dianggap menyimpang. (3) Menyalahkan orang maupun kelompok lain yang berbeda paham dengan paham yang diyakini dalam kelompok, serta mencurigai kelompok lain bahwa kelompok tersebut mempunyai niatan buruk terhadap kelompoknya. (4) Memprovokasi dengan kata-kata yang bertujuan mengajak orang 
lain bergabung untuk melakukan propaganda dalam melakukan perlawanan kepada kelompok lain secara bersama-sama.

Menurut Badan Nasional Penanggulangan Teroris (BNPT) bahaya konten radikal bagi individu sebagai berikut :

1. Munculnya sikap intoleran yaitu tidak mau menghargai pendapat atau keyakinan kelompok maupun orang lain yang dianggap berbeda dari pandangan yang dia anut.

2. Fanatik yaitu merasa bahwa kelompok atau keyakinan yang dia anut sepenuhnya benar dan menyalahkan kelompok atau keyakinan orang lain yang berbeda dari kelompoknya.

3. Eksklusif yaitu menganggap kelompoknya atau dirinya berbeda dan tidak selevel dengan kelompok maupun keyakinan diluar paham kelompoknya.

4. Revolusioner yaitu memiliki kecenderungan untuk menggunakan kekerasan dalam melakukan perbuatan guna mencapai tujuan kelompoknya.

\section{Gambar 1.2}

Contoh konten radikal di media massa
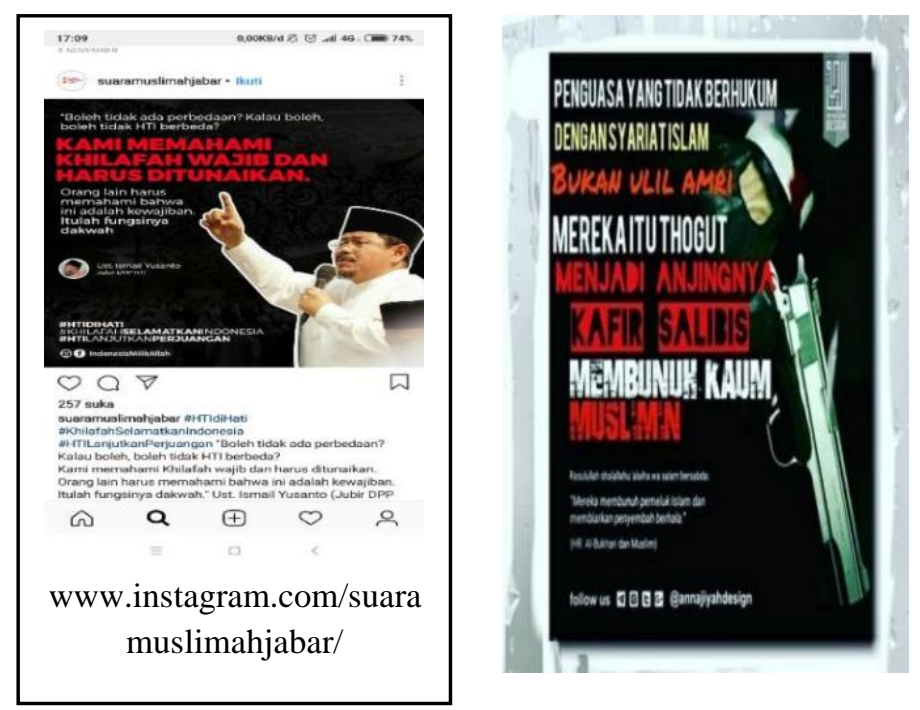

\section{Metode Penelitian}

Penelitian ini menggunakan pendekatan kuantitatif. Menggunakan populasi pengguna media sosial baik Facebook maupun Instagram sebanyak 20.000 responden. Jumlah sampel dalam penelitian ini menggunakan rumus slovin dan didapatkan sebanyak 393 responden. Pada penelitian ini menggunakan non probability sampling Peneliti menggunakan sampling purposive yakni pemlihan 
sampel yang akan diambil berdasarkan beberapa karakteristik antara lain : laki-laki atau perempuan, menyukai atau tertarik dengan paham radikal atau konten radikal, dan minimal berlangganan 2 tahun atau lebih. Teknik pengumpulan data pada penelitian ini dengan kuesioner (angket) menggunakan skala likert meliputi empat pilihan jawaban, yaitu Sangat Sesuai (SS), Sesuai (S), Tidak Sesuai (TS), dan Sangat Tidak Sesuai (STS).

Berikut adalah rician subjek dalam penelitian ini :

Tabel 1.2

Rician Subjek Penelitian

\begin{tabular}{|l|c|c|c|c|c|c|c|c|c|}
\hline \multirow{2}{*}{$\begin{array}{l}\text { Jumlah } \\
\text { Subjek }\end{array}$} & \multicolumn{2}{|c|}{$\begin{array}{c}\text { Jenis } \\
\text { kelamin }\end{array}$} & \multirow{2}{*}{$\begin{array}{c}\text { Rentang } \\
\text { Usia }\end{array}$} & \multicolumn{2}{|c|}{$\begin{array}{c}\text { Riwayat } \\
\text { pendidikan }\end{array}$} & \multicolumn{2}{|c|}{$\begin{array}{c}\text { Status } \\
\text { pekerjaan }\end{array}$} & \multicolumn{2}{|c|}{$\begin{array}{c}\text { Media yang } \\
\text { diikuti }\end{array}$} \\
\cline { 2 - 9 } & LK & Pr & & SMA & Sarjana & Swasta & PNS & FB & IG \\
\cline { 5 - 10 } & 200 & 193 & $\begin{array}{l}20-40 \\
\text { Tahun }\end{array}$ & 255 & 138 & 345 & 48 & 173 & 220 \\
\hline
\end{tabular}

Metode analisis data yang digunakan untuk mengetahui pengaruh antar variabel adalah dengan menggunakan analisis regresi linier sederhana. Sebelum teknik analisis regresi linier sederhana dilakukan, terlebih dahulu dilakukan uji asumsi klasik meliputi: uji normalitas, uji heteroskesdatisitas, dan uji linier dengan menggunakan SPSS (Statistic Product and Service Solution) 23.0 for windows.

\section{Hasil dan Pembahasan}

Tabel 1

Kategori Berdasarkan Jumlah Subjek

\begin{tabular}{|c|c|c|c|c|c|}
\hline Variabel & Pedoman & Skor & Kategori & $\sum$ Subyek & Presentase \\
\hline \multirow{2}{*}{$\begin{array}{l}\text { Konten } \\
\text { Radikal }\end{array}$} & $\mathrm{X} \geq(\mu+1 \sigma)$ & $\mathrm{X} \geq 50,85$ & Tinggi & 71 & $18,08 \%$ \\
\cline { 2 - 6 } & $(\mu-1 \sigma) \leq \mathrm{X}<(\mu+1 \sigma)$ & $39,05 \leq \mathrm{X}<50,85$ & Sedang & 264 & $67,17 \%$ \\
\cline { 2 - 6 } & $\mathrm{X}<(\mu-1 \sigma)$ & $\mathrm{X}<39,05$ & Rendah & 58 & $14,75 \%$ \\
\hline \multicolumn{7}{|c|}{ Jumlah } & 393 & $100 \%$ \\
\hline
\end{tabular}

Bahwa mayoritas responden masuk dalam kategori sedang dalam penelitian ini. Artinya sebagian besar subjek pada tingkatan kategori sedang ini intensitas dalam membaca konten radikal masih tergolong sedang. Banyaknya responden dalam kategorisasi sedang ini artinya mayoritas orang atau responden mengikuti 
atau membaca konten radikal yang ada di media sosial seperti facebook dan instagram, namun tidak hanya membaca saja subjek dalam kategori ini juga ikut serta dalam menyebarkan konten-konten radikal yang mereka lihat dimedia sosial. Hal ini bisa saja disebabkan oleh beberapa faktor yang membuat banyaknya orang suka membaca konten radikal dimedia sosial misalnya mudahnya mereka mendapatkan akses ke akun-akun yang menggungah konten tersebut, selain itu intensitas mengunggah berita atau konten radikal pada media sosial juga bisa dibilang cukup sering hal ini bisa dilihat dari beberapa akun media yang setiap harinya pasti mengunggah berita baru atau beberapa jam sekali. Lemahnya regulasi atau peraturan dari pemerintah dalam membatasi unggahan seseorang dalam media sosial juga bisa menjadi penyebab orang sering mengunggah berita-berita atau konten radikal yang bersifat mengadu domba sesama bangsa indonesia atau bahkan sesama umat beragama, hal ini bisa dilihat dari beberapa kasus saat ini yang lagi marak yaitu beredarnya berita-berita hoax yang bertujuan memecah bela bangsa indonesia. Selain itu ketersediaan waktu yang cukup banyak dari responden juga turut andil membuat seseorang sering mengakses atau membuka media sosial hal ini yang menyebabkan banyaknya orang membaca konten radikal dari akun-akun yang mereka ikuti. Meskipun responden dalam kategori sedang ini bisadigolongkan hanya sebagai pembaca aktif tapi tidak menutup kemungkinan denganbanyaknya orang dalam kategori ini yang membaca akan membuat mereka juga turut serta menyebarluaskan konten-konten radikal yang mereka baca atau dapat dimedia sosial kedalam lingkungan sekitar atau mengunggah ke akun pribadi mediasosial mereka, contohnya kita bisa melihat seringnya orang-orang dalam kategori ini meneruskan unggahan akun lain tanpa mereka mencari tahu berita atau informasi yang sedang mereka sebar, misalnya pada kasus kerusuhan 22 mei 2019mengenai aksi demo di depan Gedung BAWASLU Jakarta banyak sekali ditemukan akunakun yang turut serta menyebarkan berita-berita mengenai kerusuhan yang terjadi disana tanpa mereka mencari tahu tentang kebenaran beritatersebut.

Sedangkan pada responden konten radikal dengan tingkat kategori tinggi yang artinya seseorang dalam kategori ini membaca konten radikal bisa dibilang sering, responden dalam kategori ini adalah mereka yang membaca dan sering 
mengunggah berita-berita yang masuk kedalam ciri konten radikal mengingat responden dalam kategori ini adalah mereka yang aktif bergerak di akun-akun media sosial. Hal itu akan sangat berbahaya mengingat dampak yang akan ditimbulkan, seperti yang disampaikan oleh Badan Nasional Penangulangan Terorisme (BNPT) dampak dari pemikiran radikal pada individu adalah munculnya sikap intoleran yaitu tidak mau menghargai pendapat dan keyakinan orang lain, fanatik yaitu merasa benar sendiri terhadap kelompoknya dan menganggap yang lain salah, ekslusif yaitu membedakan diri dari kelompok lain yang berbeda, dan revolusioner yaitu cenderung menggunakan kekerasan dalam melakukan perubahan dan mencapai tujuan kelompoknya.

Dampak diatas tentunya akan sangat berbahaya dan berdampak langsung mengingat bahaya dari pemikiran radikal yang ada pada diri seseorang bisa saja akan menimbulkan tindakan-tindakan yang membahayakan apabila mereka melakukan tindakan sesuai dengan apa yang diyakini dalam hal ini berarti tindakan radikal bahkan sampai melakukan pembunuhan, karena tidak sedikit contoh dalam dunia nyata seseorang yang memiliki pemikiran radikal melakukan hal nekat dan bisa membahayakan orang lain disekitarnya, misalnya pada contoh kasus bom bunuh diri yang dilakukan oleh satu keluarga disurabaya melakukan pengeboman pada Gereja Pantekosta Pusat Surabaya, bukan hanya kasus tersebut namun masih banyak kasus lain yang dilakukan oleh orang-orang yang memiliki pemikiran radikal karena terpengaruh konten radikal dimedia massa atau ajakan seseorang. Berdasarkan hasil yang didapat dan juga teori yang sudah dijelaskan pada bab sebelumnya konten radikal memberikan andil yang cukup besar dalam menentukan tingkah laku seseorang. Konten radikal adalah informasi atau gagasan yang ada didalam media baik online maupun cetak yang didalamnya mengandung unsur radikal seperti mengajak dan memperbolehkan menggunakan kekerasan untuk orang yang berbeda faham dengan kelompoknya, bersikap intoleran serta melakukan propaganda untuk melakukan perlawanan guna membuat perubahan sistem yang dianggap sesuai oleh kelompoknya. Oleh karena itu tentunya konten radikal sangat bahaya jika dibaca atau diikuti dalam jangka waktu yang lama, dalam penelitian ini yang menjadi responden yaitu seseorang yang minimal 2 tahun atau lebih telah mengikuti atau membaca konten radikal pada media sosial. 
Sedangkan pada responden yang masuk dalam kategorisasi rendah artinya responden dalam kategori ini intensitas membacanya masih sedikit dan tidak terlalu sering ikut menyebarluaskan konten-konten radikal, namun tidak menutup kemungkinan responden pada kategori ini akan berdampak bahaya mengingat seiring berjalannyan waktu tentu orang-orang ini akan sering membaca kontenkonten radikal di media sosial, ditambah akses yang mudah didapatkan dan juga memiliki waktu yang luang dalam mengakses konten radikal yang ada dimedia sosial.

Secara umum dilihat dari banyaknya subjek yang mengikuti atau membaca konten radikal akan sangat bahaya jika dilakukan dalam jangka waktu yang lama mengingat apa yang mereka ikuti ini berkaitan dengan paham atau pemikiran radikal hal itu juga akan memicu bertambahnya jumlah pembaca karena subjek ini akan ikut serta menyebarluaskan konten-konten radikal di media sosial pribadi milik mereka sehingga tidak menutup kemungkinan orang atau teman sebagai pembaca baru akan mengikuti pola yang sama seperti yang terjadi pada mereka yang semula hanya menjadi pembaca kemudian lama-kelamaan akan ikut serta menyebarluaskan.

Tabel 1.4

Kategori Subjek Berdasarkan Ciri-ciri Konten Radikal

\begin{tabular}{|c|l|c|c|c|}
\hline Variabel & \multicolumn{1}{|c|}{ Ciri-ciri } & Mean & Persentase & Kategorisasi \\
\hline & $\begin{array}{l}\text { Mempunyai prinsip penafsiran ajaran } \\
\text { kelompok yang berbeda atau berlawanan } \\
\text { dengan tradisi yang sedang berlaku atau } \\
\text { gerakan kelompok yang sudah muncul. }\end{array}$ & 11,12 & $24,74 \%$ & Rendah \\
\cline { 2 - 5 } & $\begin{array}{l}\text { Menggunakan kekerasan yang dianggap } \\
\text { benar dalam ajaran kelompoknya. }\end{array}$ & 11,40 & $25,37 \%$ & Tinggi \\
\cline { 2 - 5 } $\begin{array}{l}\text { Konten } \\
\text { Radikal }\end{array}$ & $\begin{array}{l}\text { Menyalahkan orangmaupun kelompoklain } \\
\text { yang berbeda paham dengan paham yang } \\
\text { diyakini dalam kelompok. }\end{array}$ & 11,20 & 24,92 & Sedang \\
\cline { 2 - 5 } & $\begin{array}{l}\text { Memprovokasi dengan kata-kata yang } \\
\text { bertujuan mengajak orang lain bergabung } \\
\text { untuk melakukan propaganda dalam } \\
\text { perlawanan kepada kelompok lain secara } \\
\text { bersama-sama. }\end{array}$ & 11,21 & $24,94 \%$ & Sedang \\
\hline
\end{tabular}

Sedangkan hasil deskriptif pada ciri konten radikal diatas dapat diketahui dari jumlah mean konten radikal bahwa pada ciri-ciri kedua yaitu Menggunakan kekerasan yang dianggap benar dalam ajaran kelompoknya masuk dalam kategori tinggi yaitu sebesar 25,37\%, artinya responden dalam kategori ini memilih konten- 
konten yang memiliki ciri atau tergolong dalam ciri tersebut dan juga mempersepsikan bahwa kekerasan itu bukan suatu hal yang salah.

Sedangkan pada ciri-ciri menyalahkan orang maupun kelompok lain yang berbeda paham dengan paham yang diyakini dalam kelompok, masuk dalam kategori sedang yakni sebesar 24,92\%, begitu juga dengan ciri-ciri Memprovokasi dengan kata-kata yang bertujuan mengajak orang lain bergabung untuk melakukan propaganda dalam perlawanan kepada kelompok lain secara bersama-sama atau ujaran kebencian yakni sebesar 24,94\%, keduanya masuk dalam kategori sedang artinya sebagian basar responden memilih atau mendukung ciri-ciri ini bahkan kedua ciri-ciri ini merupakan hal yang paling disukai oleh sebagian besar responden maka tidak menutup kemungkinan subjek akan suka menyebar atau membuat konten-konten yang menjadi ciri-ciri ini.

Kemudian ciri-ciri memiliki prinsip atau penafsiran berbeda dengan kelompok pada umumnya masuk dalam kategori yang rendah yakni sebesar $24,74 \%$ artinya subjek dalam kategori ini menyukai atau memilih konten-konten dimedia sosial yang berkaitan dengan ciri tersebut tergolong sedikit jika dibanding dengan ciri konten radikal lainnya. Perbedaan-perbedaan kategori ini bisa juga disebabkan oleh persepsi individu mengenai hal-hal yang mereka sukai dan juga kontrol pada diri individu yang masih mudah terbawah oleh isi konten radikal.

Tabel 1.5

Kriteria Kategorisasi Sikap Radikalisme

\begin{tabular}{|c|c|c|c|c|c|}
\hline Variabel & Pedoman & Skor & Kategori & $\sum$ Subyek & Presentase \\
\hline \multirow{3}{*}{$\begin{array}{l}\text { Sikap } \\
\text { Radikalis } \\
\text { me }\end{array}$} & $\mathrm{X} \geq(\mu+1 \sigma)$ & $x \geq 88,13$ & Tinggi & 73 & $18,57 \%$ \\
\hline & $(\mu-1 \sigma) \leq X<(\mu+1 \sigma)$ & $71,11 \leq \mathrm{X}<88,13$ & Sedang & 253 & $64,37 \%$ \\
\hline & $\mathrm{X}<(\mu-1 \sigma)$ & $\mathrm{X}<71,11$ & Rendah & 67 & $17,06 \%$ \\
\hline \multicolumn{4}{|c|}{ Jumlah } & 393 & $100 \%$ \\
\hline
\end{tabular}

Hasil deskriptif pada skala sikap radikalisme diketahui bahwa mayoritas responden dalam penelitian ini yang tergolong dalam kategori sedang yaitu sebesar $64,37 \%$ atau 253 orang artinya responden dalam kategori ini juga mengikuti kegiatan-kegiatan terkait perilaku radikal namun mereka cukup mampu untuk mengendalikan dirinya agar tidak sampai melakukan tindakan radikal diluar batas 
seperti melakukan tindakan bom bunuh diri ataupun melukai orang lain, bagi mereka dorongan dari lingkungan sekitar akan sangat berpengaruh dalam memunculkan sikap radikal yang mereka miliki.

Kemudian yang masuk dalam kategori tinggi yaitu 18,57\% atau 73 orang, subjek yang masuk dalam kategori ini artinya mereka yang memiliki sikap radikal tinggi dan sudah atau sering melakukan tindakan-tindakan radikal terkait paham yang mereka yakini.

Sedangkan yang masuk dalam kategori rendah yaitu $17.06 \%$ atau 67 orang, subjek yang masuk dalam kategori ini masih memiliki sikap radikal rendah atau sudah memiliki bibit-bibit mengenai sikap radikal artinya sikap radikal mereka tidak akan muncul jika tidak ada dorongan yang kuat dari lingkungan disekitar yang mendorong mereka untuk melakukan tindakan terkait radikalisme disini peran stimulasi atau orang-orang disekitar mereka akan sangat berpengaruh terhadap munculnya sikap radikal yang sudah mereka miliki.

Tabel 1.6

Kategorisasi Aspek Sikap Radikalisme

\begin{tabular}{|l|l|c|c|c|}
\hline Variabel & \multicolumn{1}{|c|}{ Aspek } & Mean & Persentase & Kategorisasi \\
\hline Sikap \begin{tabular}{l} 
Radikalisme \\
\cline { 2 - 5 }
\end{tabular} & $\begin{array}{l}\text { Attitude Toward the } \\
\text { Behavior }\end{array}$ & 32,92 & $33,06 \%$ & Rendah \\
\cline { 2 - 5 } & Subjective Norm & 33,08 & $33,22 \%$ & Sedang \\
\cline { 2 - 5 } & $\begin{array}{l}\text { Percived Behavioral } \\
\text { Control }\end{array}$ & 33,55 & $33,70 \%$ & Tinggi \\
\hline
\end{tabular}

Sedangkan untuk kategori aspek sikap jumlah mean masing-masing aspek sikap radikalisme dan dapat diketahui bahwa aspek Percived Behavioral Control masuk dalam kategori tinggi yakni sebesar 33,70\%, artinya munculnya perilaku radikal pada diri seseorang erat kaitannya dengan sumber daya yang dibutuhkan dan kemampuan yang diperlukan serta kendala yang dihadapi terkait bentuk atau perilaku apa yang akan dimunculkan.

Sedangkan pada aspek Subjective Norm masuk dalam kategori sedang yakni sebesar $33,22 \%$, artinya disini norma dan lingkungan sosial memberikan pengaruh yang cukup untuk bisa memunculkan sikap radikal seseorang hal ini bisa muncul 
dari orang-orang disekitar maupun dari konten-konten radikal yang sering mereka baca.

Untuk aspek Attitude Toward the Behavior masuk dalam kategori rendah yakni hanya sebesar 33,06\%, artinya sikap atau persepsi terhadap tingkah laku yang akan ditampilkan mengenai konsekuensi positif atau negatif terhadap dirinya akan memengaruhi seseorang dalam melakukan perilaku radikal, jika subjek ini sudah yakin bahwa perilaku tersebut bermanfaat maka subjek dengan yakin akan melakukan tindakan tersebut.

\section{Kesimpulan dan Saran}

Berdasarkan hasil penelitian bahwa ada pengaruh antara konten radikal terhadap sikap radikalisme. Pada uji regresi linier sederhana diperoleh probabilitas atau signifikansi $0,000<0,05$, maka Ha diterima maka dapat disimpulkan variabel terdapat pengaruh konten radikal terhadap sikap radikalisme. Hasil penelitian diperoleh $\mathrm{R}$ square sebesar $0,673=67,3 \%$ artinya kontribusi atau sumbangan konten radikal terhadap sikap radikalisme pada responden sebesar 67,3\% sedangkan sisanya sebesar $32,7 \%$ dijelaskan oleh faktor lain yang tidak diukur dalam penelitian ini. Artinya konten radikal disini memberikan pengaruh yang sangat besar terhadap pembentukan sikap radikal terhadap seseorang yakni sebesar $67,3 \%$.

Ciri konten radikal yang menjadi minat responden atau yang tergolong kategori tinggi yaitu menggunakan kekerasan yang dianggap benar dalam ajaran kelompok termasuk tindakan melawan pemerintah dan melakukan pembunuhan.

Aspek yang paling memengaruhi pembentukan tingkah laku adalah Perceived Behavioral Control atau kontrol perilaku yang dipersepsikan maksudnya adalah hal yang berkaitan dengan persepsi individu mengenai kendala yang dihadapi terkait mudah atau tidaknya mewujudkan suatu tingkah laku tertentu, persepsi kontrol tingkah laku ditentukan oleh keyakinan individu mengenai ketersediaan sumber daya berupa peralatan, kompatibelitas, kompetensi, dan kesempatan yang mendukung atau menghambat prilaku yang diprediksi dan besarnya peran sumber daya tersebut. 
Saran bagi subjek penelitian ini adalah Mengurangi penggunaan media sosial dan membatasi diri dalam membaca atau melihat konten-konten radikal. Mulai menjauhi kelompok ataupun orang yang terindikasi menjadi bagian dari kelompok radikal, dan Berhati-hati menggunakan persepsi terhadap tingkah laku karena pada dasarnya diri sendirilah yang mengontrol apakah akan melakukan tindakan radikal atau tidak.

Sedangkan bagi masyarakat yaitu dapat berperan aktif dalam mencegah maupun mengurangi akses kemedia sosial terutama yang berkaitan dengan membaca konten-konten radikal, dan aktif dalam menjaga kerukunan dan keutuhan NKRI, karena hal itu akan berdampak langsung terhadap pembentukan sikapradikal pada seseorang.

Untuk pemerintah dan pengelolah media sosial yaitu lebih memperketat aturan dan regulasi terkait hal yang berkaitan dengan konten radikal baik itu penyebarannya maupun orang yang membuat konten tersebut, dan lebih memperketat akes upload ataupun membagikan postingan orang lain jika hal itu terindikasi masuk dalam kategori konten radikal agar pengguna tidak semakin banyak yang menjadi pembaca atau penonton konten radikal dimedia sosial karena hal itu berdampak bahaya bagi individu maupun masyarakat.

Untuk peneliti selanjutnya yang akan melakukan penelitian serupa diharapkan melakukan penelitian yang lebih luas lagi, misalnya meneliti lebih dari satu variabel psikologi sehingga nantinya bisa mengetahui keberagaman pengaruh maupun hubungan yang didapatkan, selain itu juga diharapkan bisa mengungkap beberapa faktor lain yang mempengaruhi misalnya lingkungan sekitar, Lembaga Pendidikan dan ajaran Agama serta faktor dari orang-orang yang dianggap penting. Selain itu diharapkan peneliti selanjutnya bisa bertemu langsung dengan subjek saat pengambilan data kepada responden agar mengetahui reaksi subjek secara detail. 


\section{Daftar Pustaka}

Ahmadi, A. (2009). Psikologi Sosial. Jakarta: PT Rineka Cipta

Anonim. (2018). Pengeboman Gereja. https://www.liputan6.com.

Anonim. (2018). Data Pelaku Radikalisme. https://www.bnpt.go.id.

Ajzen, I. (2005). Attitudes, Personality and Behavior, (2nd edition), Berkshire, UK: Open University Press-McGraw Hill Education.

Arifin, B. S. (2015). Psikologi Sosial. Bandung: Pustaka Setia

Arifin, S. (2005). Idologi dan Praksisi Gerakan Sosial Kaum Fundamentalis. Malang: UMMPress

Azwar, S. (2013). Sikap Manusia Teori Dan Pengukurannya. Yogyakarta: Pustaka Pelajar

Baron, R.A. \& Donn Byrne. (2012). Psikologi Sosial Jilid 2 Edisi Kesepuluh. Erlangga: Jakarta

Biroli, A \& Edi. F. R. S. (2017). Psikologi Sosial. Bangkalan: UTM Press

Ghifari, F. (2017). Radikalisme Internet. Bandung: UIN Sunan Gunung Djati

Jainuri, A. (2016). Radikalisme dan Terorisme, Akar Ideologi dan Tuntutan Aksi. Malang: Intrans Publishing

Jainuri, dkk. (2003). Terorisme Dan Fundamentalisme Agama. Malang: UMMPress

Myers, D. G. (2014). Psikologi Sosial. Jakarta: Salemba

Neliati, E. (2013). Pengaruh Media Internet Terhadap Sikap Konsumen Online Pada Program Studi Ilmu Komunikasi Angkatan 2011. Samarinda: Universitas Mulawarman. https://ejournal.ilkom.fisip-unmul.ac.id/

Poerwadarminta. W. J. S (2007). Kamus Umum Bahasa Indonesia. Edisi ketiga. Jakarta: Balai Pustaka

Ramdhani, N. (2011). Penyusunan Alat Pengukur Berbasis Theory of Planned Behavior. Buletin Psikologi Vol 19. No2. 2011: 55-69. Yogyakarta: Universitas Gadjah Mada. https://jurnal.ugm.ac.id

Sobur, A. (2013). Psikologi Umum. Bandung: Pustaka Setia 
Sugiyono. (2012). Metode Penelitian Kuantitatif Kualitatif dan R\&D. Alfabeta: Bandung

Winardi. (2012). Manajemen Perilaku Organisasi. Edisi Revisi. Jakarta: Prenada Media Grup

Zen, F. (2012). Radikalisme Retoris. Jakarta: Bumen Pustaka Emas 